Contacts

Publisher: Ben Crowe

Editor: Paul Smaglik

Marketing Manager: David Bowen

US Head Office, New York 345 Park Avenue South, 10th Floor New York, NY 10010-1707

Tel +1 8009897718

$\mathrm{Fax}+18009897103$

e-mail: naturejobs@natureny.com

US Sales Manager/ Corporations:

Peter Bless

Classified Sales Representatives:

Phone: +1 8009897718

Pennsylvania, New York

Maryland/ Latin America/ NIIH

Michael McGillion

Midwest USA:

Wade Tucker

East USA/ Canada:

Janine Taormina

\section{San Francisco Office}

Classified Sales Representative:

Michaela Bjorkman

West USA/ West Corp. Canada

225 Bush Street, Suite 1453

San Francisco, CA 94104

Tel +14157813803

Fax +14157813805

e-mail:m.bjorkman@naturesf.com

\section{European Head Office,}

London

The Macmillan Building, 4 Crinan Street,

London N1 9XW, UK

Tel +44 (0) 2078434961

Fax +44 (0) 2078434996

e-mail: naturejobs@nature.com

\section{Naturejobs Sales Director:}

Nevin Bayoumi (4978)

Production Manager: Billie Franklin

To send materials use London

address above

Tel +44 (0) 2078434814

Fax +44 (0) 2078434996

e-mail: naturejobs@nature.com

\section{Naturejobs web development}

Tom Hancock

Naturejobs online production

Stefan Hales

European Satellite Office

Germany/ Austria/ Italy/

The Netherlands/ Belgium:

Patrick Phelan, Odo Wulffen

e-mail:p.phelan@nature.com o.wulffen@nature.con

Japan Head Office, Tokyo MG Ichigaya Building (5F),

19-1 Haraikatamachi,

Shinjuku-ku,

Tokyo 162-0841

Tel +81332678751

Fax +81332678746

Asia-Pacific Sales Director

Rinoko Asami

e-mail: rasami@naturejpn.com

\title{
naturejobs
}

\section{A delicate balance}

W

hen ten new member nations officially became part of the European Union (EU) earlier this month, it added a huge number of new recruits - and opportunities - to the region's scientific job market. But this expansion will require recruiters across the EU to strike a somewhat delicate balance. How, for example, can the wealthier EU nations in the west absorb thousands of scientists from the poorer new members without stretching their own resources and without draining the eastern countries of their intellectual capital?

The west should certainly prove to be a big draw for researchers in the east. The Baltic nations have a tradition of rigorous training in maths, physics and chemistry. These skills are in short supply in the west, so promising students could well find themselves wooed with promises of more funds and better infrastructure. Indeed, the west has regularly looked east for such skills, but EU membership changes the rules for visas and improves mobility.

This increased mobility carries with it the threat of an east-west brain drain. With some prudence and creativity, this could be avoided. One approach is to set up networks, such as ScanBalt, that emphasize collaborations between the east and west. Alternatively, efforts that encourage researchers within the eastern nations can help to persuade them to stay at home. For example, last summer, the medicinal-chemistry department at the University of Szeged in Hungary held a symposium that paired undergraduates with more senior scientists in a bid to give the youngsters more chances to publish.

Sadly, it is inevitable that many young scientists from the new member states will head west to seek their fortune. Hopefully, this will lead to a strengthening of infrastructure and investment in the new members that will eventually draw them, and others, east.

\section{Paul Smaglik}

Naturejobs editor
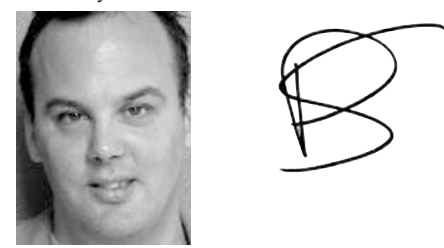

\section{Contents}

\section{POSTDOCS AND STUDENTS}

Making the switch between industry and academia

\section{CAREER VIEW}

Bricks \& Mortar

Switzerland switches on supercomupters Graduate Journal

A lab affair

Movers

Norbert Jousten

\section{WWW.NATUREJOBS.COM}

Career centre

Information on the scientific job market

FOCUS

SPOTLIGHT

RECRUITMENT

ANNOUNCEMENTS

EVENTS 